Review

\title{
Organophosphate-degrading metallohydrolases: Structure and function of potent catalysts for applications in bioremediation
}

\author{
Gerhard Schenk $^{\mathrm{a}, *, 1}$, Irsa Mateen ${ }^{\mathrm{b}, 1}$, Tee-Kheang $\mathrm{Ng}^{\mathrm{c}}$, Marcelo M. Pedroso ${ }^{\mathrm{a}}$, \\ Nataša Mitić $^{\mathrm{d}}$, Miguel Jafelicci Jr. ${ }^{\mathrm{e}}$, Rodrigo F.C. Marques ${ }^{\mathrm{e}}$, \\ Lawrence R. Gahan ${ }^{a}$, David L. Ollis ${ }^{\mathrm{c}, * *}$ \\ a School of Chemistry and Molecular Biosciences, The University of Queensland, Brisbane QLD 4072, Australia \\ ${ }^{\mathrm{b}}$ Centre of Agricultural Biochemistry and Biotechnology, University of Agriculture, Faisalabad, Pakistan \\ ${ }^{\mathrm{c}}$ Research School of Chemistry, Australian National University, Canberra 0200, Australia \\ ${ }^{\mathrm{d}}$ Department of Chemistry, Maynooth University, Maynooth, Co. Kildare, Ireland \\ e Institute of Chemistry, São Paulo State University - UNESP, Araraquara 14800-900, Brazil
}

\section{Contents}

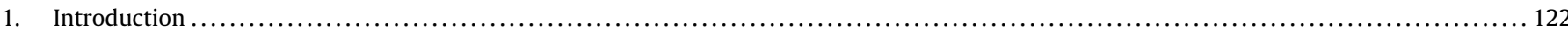

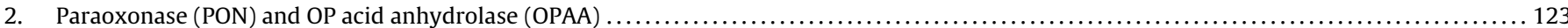

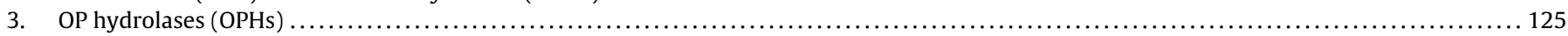

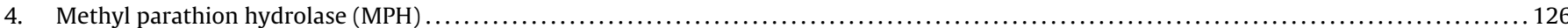

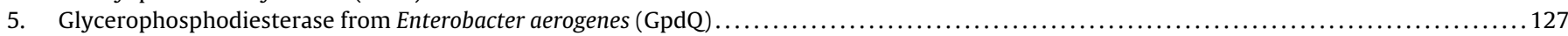



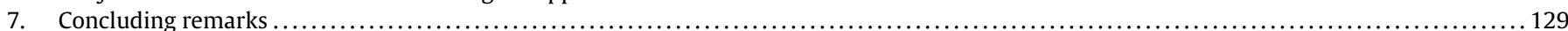

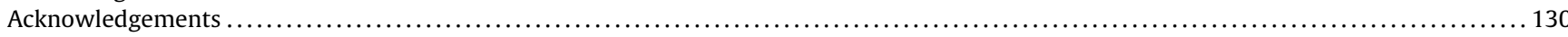

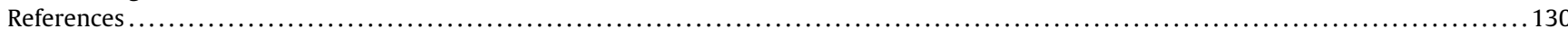

\section{A R T I C L E I N F O}

\section{Article history:}

Received 11 February 2016

Accepted 9 March 2016

Available online 17 March 2016

\section{Keywords:}

Metallohydrolases

Organophosphate pesticides and nerve agents

Bioremediation

Enzyme immobilization

Catalysis

\begin{abstract}
A B S T R A C T
Organophosphate compounds (OPs) have been employed in the agricultural industry as pesticides and insecticides for several decades. Many of the methods used currently for the detoxification of OPs are harmful and possess serious environmental consequences. Therefore, utilizing enzymes for the detection and decontamination of OPs is gaining increasing attention as an efficient and clean bioremediation strategy. Microbial enzymes, such as OP hydrolases, OP acid anhydrolases or methyl parathion hydrolase (MPH), are potent agents for OP decontamination. Their biochemical properties and biotechnological applications are discussed in this review, including a discussion on methods that may be employed to immobilize such enzymes, and essential steps to generate reusable and affordable biocatalytic systems for use in bioremediation and biorestoration.
\end{abstract}

(C) 2016 Elsevier B.V. All rights reserved.
Abbreviations: $\mathrm{BChE}$, butyrylcholinesterase; $\mathrm{CB}$, carbon black; CBD, cellulosebinding domain; CNT, carbon nanotube; DFP, diisopropylfluorophosphate; GpdQ, glycerophosphodiesterase; HFB, hollow fiber bioreactor; MBL, metallo- $\beta$ lactamase; MPH, methyl parathion hydrolase; OP, organophosphate; OPAA, OP acid anhydrolase; OPH, OP-degrading hydrolase; PEG, polyethylene glycol; PNP, p-nitrophenol; PON, paraoxonase; PTE, phosphotriesterase; QD, quantum dots.

* Corresponding author. Tel.: +61 733654144 .

** Corresponding author. Tel.: +61 2 6125-4377.

E-mail addresses: schenk@uq.edu.au (G.Schenk), ollis@rsc.anu.edu.au (D.L. Ollis).

1 These authors contributed equally to the preparation of the manuscript.

\section{Introduction}

Organophosphate ${ }^{2}$ pesticides (OPs) are important in agriculture, accounting for approximately $40 \%$ of the total global pesticide usage (Fig. 1) [1-3]. OPs are also produced as chemical warfare agents (CWA); 200,000 tons of these agents are thought to be

\footnotetext{
2 The term organophosphate is often used to denote a class of pesticides or nerve agents that are triesters of phosphoric, phosphonic and phosphinic acid and sulfurcontaining compounds. While there are formal nomenclature conventions for these compounds they are usually referred to by their common names in the literature and this convention is followed here.
} 
(a)<smiles>[Y20]CCN(C(C)C)C(C)C</smiles>

(b)<smiles>CCOP(=S)(OCC)Oc1nc(Cl)c(Cl)cc1Cl</smiles>

Chlorpyriphos<smiles>CCOC(=O)CC(SP(=S)(OC)OC)C(=O)OCC</smiles>

Methyl parathion

Malathion

Fig. 1. Structures of OPs representing nerve agents and pesticides.

stored throughout the world $[4,5]$. These compounds are generally toxic, primarily due to their ability to irreversibly inhibit acetylcholinesterase [6]. OPs are partially water soluble and can easily enter the soil and ground water and, being mutagenic, they have been linked to a number of nervous and immune system-related diseases [7-23]. In both developing and developed countries OPs are also a common cause of poisoning by occupational exposure or deliberate self-harm and environmental contamination [1,2,8-16,24-39].

Disposing of OPs can be problematic. Stockpiles dumped in landfills can leach into the surrounding soil while chemical degradation can result in the production of toxic by-products [40]. Incineration of OPs is an approved but costly process that can also result in toxic emissions [41-43]. An efficient "green and clean" approach to degrade OPs is thus much desired, and enzymes expressed in some soil-dwelling microorganisms may be an ideal tool for this purpose. The history of OP-degrading enzymes dates back to 1946 when hydrolysis of diisopropylfluorophosphate (DFP) was observed in mammalian tissue extracts [44]. In 1973 it was discovered that the soil bacterium Flavobacterium sp. (strain ATCC 27551) is able to thrive in an environment where the OP diazinon is the sole carbon source [45]. Several other microorganisms, including Agrobacterium radiobacter, Enterobacter aerogenes and Pseudomonas diminuta have since been shown to possess the enzymatic machinery to degrade OPs $[43,46-48]$. Common to these organisms is that they have evolved an enzymatic activity that is very effective in hydrolyzing the OP triesters into di- and monoesters, and ultimately phosphate; the products of these hydrolytic reactions are generally far less harmful than their parent OP compound.

In this review several OP-hydrolyzing enzymes will be discussed with a view to describing their general physicochemical features and how they can be utilized in the context of bioremediation, i.e. the degradation of harmful OP compounds into less or non-toxic products. We realize that we have been selective in our focus and apologize in advance to authors whose significant contributions to the field may not have been covered in detail. For instance, insects are one of the main targets of OP pesticides and it is thus not surprising that they have developed some resistance, involving in particular a family of esterases [49]. However, since these enzymes do not require metal ions for their function they will not be discussed further here. Also, we like to stress that the purpose of the article is to describe enzymatic systems in context of their potential for applications in bioremediation, not their mechanistic details (which are outlined in a series of primary literature as indicated in relevant sections).

\section{Paraoxonase (PON) and OP acid anhydrolase (OPAA)}

In 1946 Mazur, studying rabbit tissue samples, discovered the first example of an enzyme capable of degrading an OP, DFP [44]. Due to its ability to hydrolyze the OP paraoxon (Fig. 1) this OP acid anhydrolase (OPAA) was given the name paraoxonase (PON) [50-52]. However, it was subsequently found that this enzyme is rather promiscuous acting on a broad spectrum of diverse substrates, including a range of OPs and lactones [53,54]. While this broad substrate range complicates the assessment of the precise biological function(s) of PON, there is strong evidence that links the enzyme to atherosclerosis [55-57].

Based on sequence homology PON enzymes are divided into three groups, PON1-PON3 [58]. PON1 is the best studied group in this family of enzymes and has been identified in a variety of higher organisms, including human, rabbit, bovine, dogs, cats and horses [59]. PON1 appears to be the only family member with efficient OP hydrolase activity [53]; the enzyme is likely to act as a lactonase in vivo [54] but is capable of degrading a variety of OPs including the oxon metabolites of parathion, diazinon and chlorpyriphos, as well as the nerve agents Sarin and Soman [52]. In directed evolution experiments it was demonstrated that the substrate preference of PON1 can easily be modified, underlining this enzyme's potential in the detoxification of OPs, in particular for victims suffering from poisoning [60]. The enzyme consists of about 350 amino acids. The crystal structure of rabbit PON1 was solved to $2.2 \AA$ resolution (Fig. 2), showing a six-bladed $\beta$-propeller overall structure [60]. Importantly, the active site contains two $\mathrm{Ca}^{2+}$ ions, one with a structural role, the second required for catalysis [58]. In the proposed model for the reaction mechanism the substrate coordinates to the catalytic calcium ion (labeled Ca1) prior to a nucleophilic attack by a hydroxide ion that does not directly coordinate to this $\mathrm{Ca}^{2+}$ but is activated via hydrogen bonding interactions involving two conserved histidine residues in the active site (Fig. 2) [60].

OPAAs are frequently categorized in two classes, "squid-type" and "Mazur-type" $[61,62]$. The former prefers DFP to Soman as substrate and requires $\mathrm{Ca}^{2+}$ ions for activity [63]. The $\mathrm{Ca}^{2+}$-dependent PON1 described in the previous section therefore classifies as a 

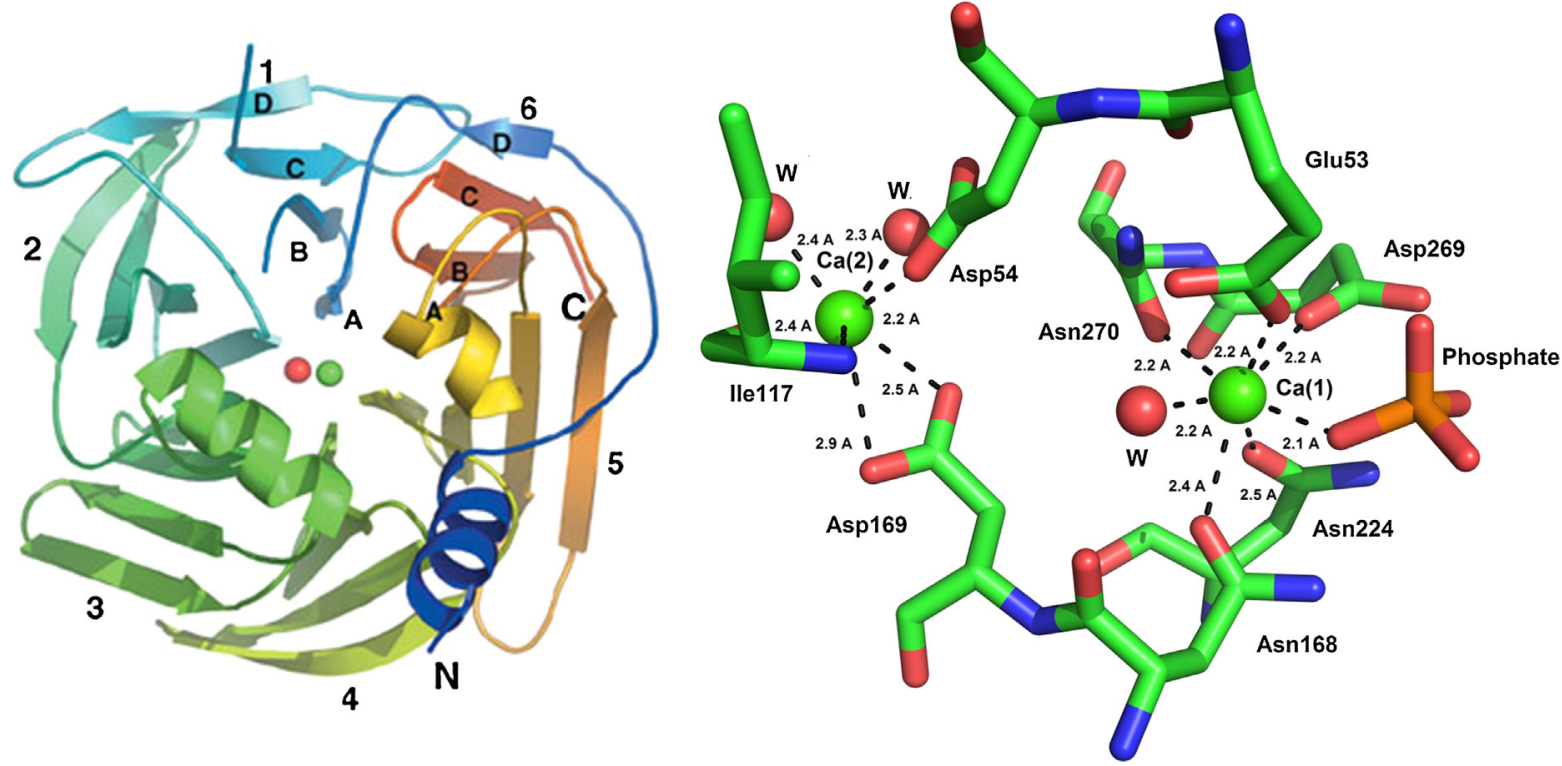

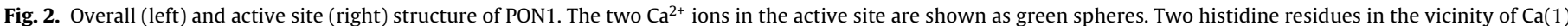

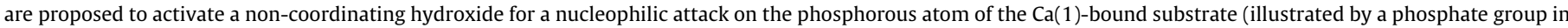
the structure). W represents water molecules. The figure was modified from [60].

"squid-type" OPAA, the name referring to the initial discovery of a $\mathrm{Ca}^{2+}$-dependent OPAA in the squid Loligo pealei in 1966 [62,64]. In contrast, the "Mazur-type" OPAAs are characterized by being more efficient catalysts for the hydrolysis of Soman than DFP, and their activity is stimulated by $\mathrm{Mn}^{2+}$ ions. Paradigm examples are OPAAs purified from a number of Alteromonas species, initially strain JD6.5, and subsequently also in $A$. undina, $A$. haloplanktis and $A$. macleodii [63,65-69]. These OPAAs are characterized by their broad substrate specificity toward a wide variety of OPs, especially the highly toxic G-type nerve agents Sarin, Soman and Tabun. Specifically, they are highly active against P-F bonds, but far less so against P-O or P-C bonds [63]. Crystal structures for the enzymes from Strain JD6.5 and A. macleodii were recently determined to $2.3 \AA$ and $1.8 \AA$, respectively $[68,69]$. The two enzymes share more than $60 \%$ sequence identity and also display a high degree of structural similarity with an rmsd of $0.8 \AA$ for 421 aligned carbon backbone atoms [68]. While the OPAA from Strain JD6.5 is monomeric the A. macleodii enzyme is dimeric in solution $[68,69]$. Despite these apparent differences in their oligomeric structure the active site geometry in these two enzymes is virtually identical. Their active sites contain two closely spaced $\mathrm{Mn}^{2+}$ ions, separated by $\sim 3.3 \AA$ (Fig. 3). The two metal ions are bridged bidentately by the carboxyl groups of an aspartate and a glutamate side chain. In addition, an oxygen atom from either a water molecule (in A. macleodii OPAA) or presumably a glycolate (present in the crystallization mixture of Strain JD6.5 OPAA) links the two $\mathrm{Mn}^{2+}$ ions. It is interesting to point out that the active site geometry of OPAA is very similar to that of the enzyme aminopeptidase P (AMPP) from Escherichia coli [70,71]; the ligands of the $\mathrm{Mn}^{2+}$ ions are invariant. AMPP, and hence OPAA, belongs to the family of prolidases, a group of enzymes that also includes methionyl aminopeptidase (MetAP) [72,73] as well as numerous bacterial, archeal and human prolidases, $\mathrm{Mn}^{2+}$-dependent enzymes that hydrolyze specific peptide bonds $[74,75]$. Apart from the conservation of their active sites these enzymes also share considerable similarity in their overall structures, which are composed of two domains, an $\mathrm{N}$ - and $\mathrm{C}$-terminal one. The $\mathrm{C}$-terminal domain exhibits a "pita bread" fold that contains the dinuclear metal ion center (Fig. 3). In mammals prolidases are involved in the collagen metabolism; their role in bacteria and archaea is still unknown as the natural substrate(s) has not yet been identified. Similarly, the natural substrates of OPAAs are still unknown but these enzymes were demonstrated to have significant in vitro prolidase activity $[63,76]$. It is thus not surprising that variants of prolidases have been isolated from hyperthermophilic bacteria and demonstrated
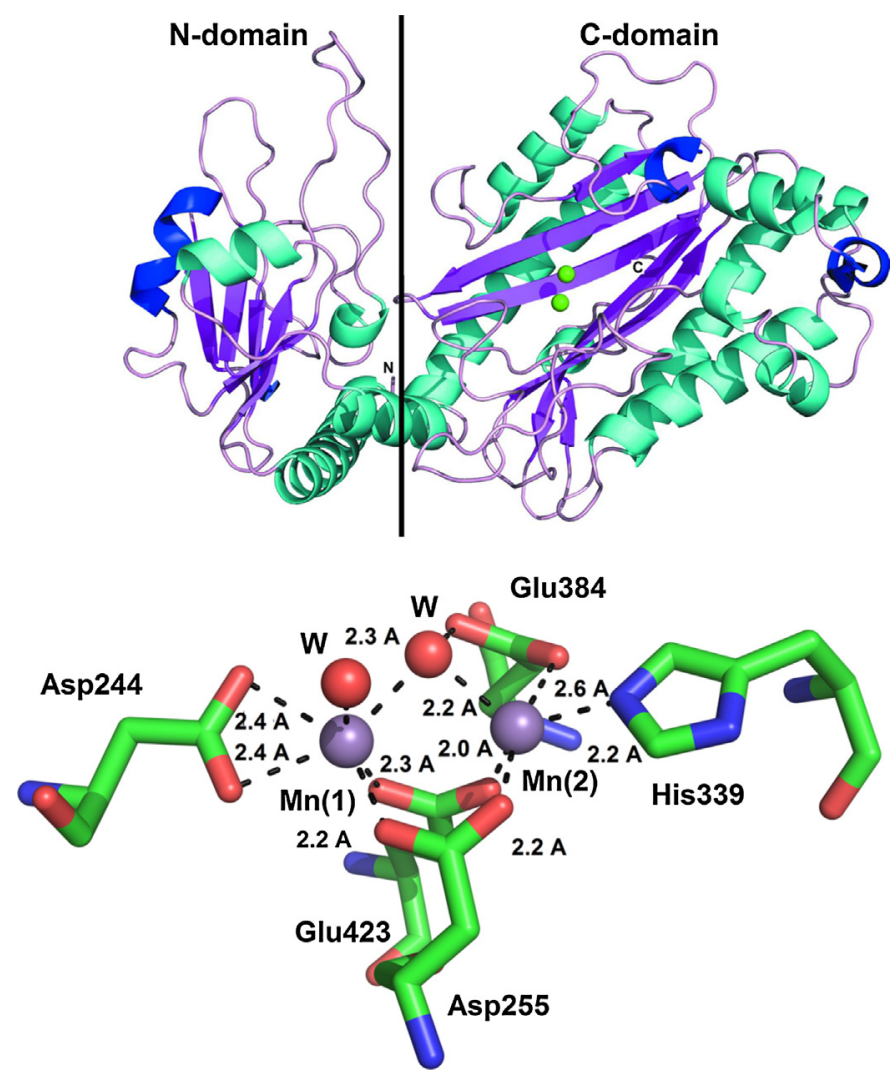

Fig. 3. Overall (top) and active site (bottom) structure of OPAA. The monomer contains two distinct domains. The active site is located in the C-terminal domain and contains two bound $\mathrm{Mn}^{2+}$ ions (shown as purple spheres). The metal ions are bridged via two carboxyl groups and a water molecule (red sphere). The figure was modified from [68]. 
to have low levels of OP-degrading activity that could be improved using directed evolution [77]. For example, the prolidase from Pseudomonas horikoshii (Phprol) has been the subject of in vitro evolution experiments in which a $P h 1$ prol gene library was constructed and screened for mutants that show increased prolidase activity at $30^{\circ} \mathrm{C}$. Four mutants were found with improved catalytic parameters at various temperatures for the hydrolysis of several OP nerve agents, including p-nitrophenol Soman $[41,78]$.

\section{OP hydrolases (OPHs)}

"Squid-type" and "Mazur-type" OPAAs are not the only enzymes capable of hydrolyzing OP pesticides and nerve agents. The introduction of pesticides for agricultural applications triggered the evolution of OP-degrading hydrolases (OPHs) in a number of soil-dwelling microorganisms $[46-48,79,80]$. One of the best characterized of these enzymes is the phosphotriesterase (PTE) that was initially identified (in 1973) in Flavobacterium sp ATCC 27551 and then $P$. diminuta [45,81]. The gene encoding PTE is localized on extrachromosomal plasmids and may thus be rapidly transferred among different microorganism (i.e. via a horizontal gene transfer reminiscent of that associated with the rapid spread of the antibiotic-degrading dinuclear metallo- $\beta$-hydrolases) [80]. To a large extent PTE has a substrate specificity that resembles that of OPAA, being able to hydrolyze compounds such as Sarin, Soman, Paraoxon and their derivatives [82,83]. However, in contrast to OPAA, PTE is also capable of hydrolyzing VX [79]. Genetic engineering has been used to produce variants of PTE with improved catalytic properties toward selected OPs. As an example, a variant in which the histidine at position 254 was replaced by an arginine exhibits a four-fold increase in the rate of hydrolysis of Demeton-S, but 14 - and $\sim 180$-fold decreases for Paraoxon and DFP, respectively [84]. Directed evolution has also been utilized to increase the catalytic efficiency toward poor substrates such as Chlorpyrifos (Fig. 1) [85].

Several crystal structures of PTE (in the presence of various substrate analogs, products, etc.) have been reported [46,84,86-88]. A representative structure is shown in Fig. 4. The active site accommodates two closely spaced divalent metal ions ( $\sim 3.5-4 \AA$ apart) but unlike in OPAAs or prolidases the in vivo metal ion content is subject to debate; catalytic activity can be reconstituted with a range of metal ions including $\mathrm{Zn}^{2+}, \mathrm{Mn}^{2+}, \mathrm{Cd}^{2+}$ and $\mathrm{Co}^{2+}[89,90]$. In contrast to OPAA only one amino acid links the two metal centers, a carboxylated lysine residue. However, a bridging water/hydroxide molecule is again ideally located to initiate a nucleophilic attack on the bound substrate. A structural comparison of the active sites of PTE and OPAA indeed demonstrated that despite a lack of discernable similarity in overall structure and amino acid sequence the catalytic centers of the two enzymes are geometrically similar, leading to the proposal that they are also employing a conserved mechanistic strategy [69].

Very closely related to PTE is the OP-degrading enzyme from Agrobacterium radiobacter (OpdA), with $\sim 90 \%$ sequence identity shared between the two enzymes $[47,90,91]$. These enzymes have similar substrate specificities with OpdA displaying a preference for methyl-substituted while PTE prefers ethyl-substituted (e.g. methyl- vs ethyl-paraoxon) [47]. The major difference between PTE and OpdA is their respective stability, with the former losing activity as a consequence of losing metal ions [92]. This difference in stability is also reflected in the effect of $\mathrm{pH}$ on their catalytic activities. PTE generally reaches optimal activity at $\mathrm{pH}$ values above 6.0 while OpdA is still efficient at $\mathrm{pH}$ values as low as 4.0 $[90,93]$. A recent study demonstrated that these functional variations between PTE and OpdA are likely to be associated with amino acid substitution in the second coordination sphere; while both enzymes have nearly identical metal ion binding sites (the identities and locations of the metal ion ligands are invariant; Fig. 4 [94]) the substrate binding pocket of OpdA only is characterized by the presence of a hydrogen bonding network that connects the metal ion and substrate binding sites [90]. This study also demonstrated that a single mutation in the second coordination sphere can alter the substrate specificity of OpdA, thus making this enzyme a good (and flexible) candidate for the development of a biocatalyst with a desired preference for particular OP substrates. Similar to PTE the native metal ion composition of OpdA is unclear. While atomic absorption and anomalous scattering measurements are consistent with the presence of an $\mathrm{Fe}^{2+}-\mathrm{Zn}^{2+}$ center [95], in vitro studies demonstrated that the di-Co ${ }^{2+}, \mathrm{di}-\mathrm{Mn}^{2+}$ and $\mathrm{di}-\mathrm{Cd}^{2+}$ derivatives are significantly more reactive and efficient than the heterodinuclear combination $[90,93]$. These studies also indicated that in particular the di-Co ${ }^{2+}$ derivative of OpdA is of interest for practical applications as it not only maintains a high activity over a broad $\mathrm{pH}$ range, but it reaches a maximum at $\mathrm{pH} 11$. Spectroscopic and kinetic studies revealed that this derivative of OpdA displays
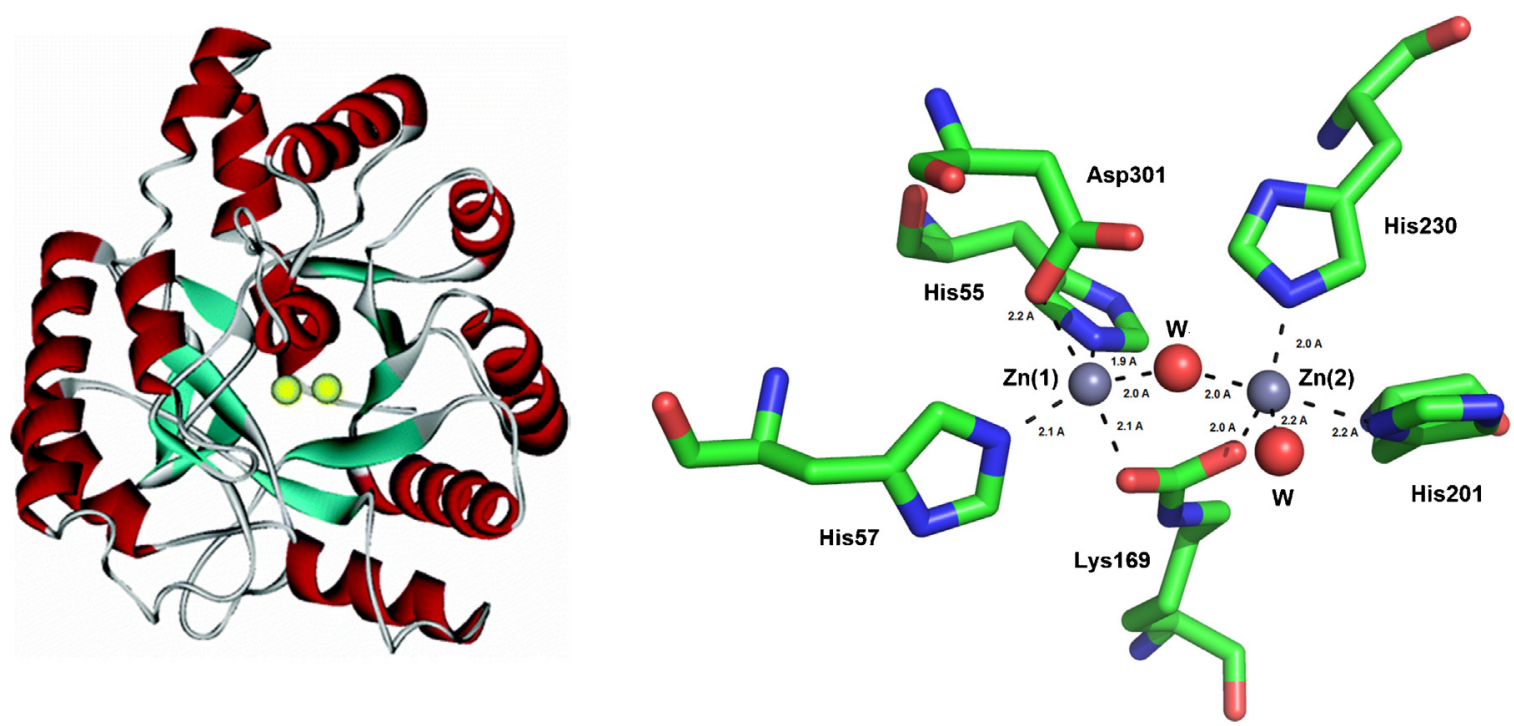

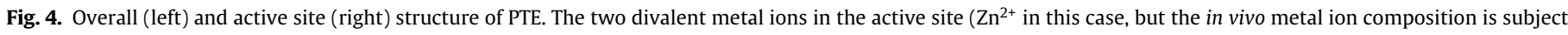
to debate) are shown as gray spheres and are linked via a carboxylated lysine residue and a water molecule. The figure was modified from [86]. 
a mechanistic flexibility whereby a metal ion-bridging hydroxide acts as hydrolysis-initiating nucleophile (as is the case for most OPdegrading enzymes, as discussed in this review) at lower $\mathrm{pH}$ values, whereas a hydroxide bound to one metal ion only fulfills this role at higher $\mathrm{pH}[90,93,96]$.

OP-degrading enzymes such as PTE and OpdA have great promise in bioremedial applications, in part due to their high catalytic efficiencies and enzymatic stability, but and in particular for OpdA, also due to their functional plasticity. As pointed out in the previous section the metal ion composition may influence the reactivity and mechanism of the enzymes, while a single amino acid substitution may alter the substrate preference [93]. In an attempt to develop desired variants of OpdA directed evolution experiments were carried whereby cell growth of $E$. coli cells that recombinantly express OpdA was coupled to OP-degrading enzyme activity using the pesticide Methyl Paraoxon as sole phosphorus source [97-99]. Using this approach it was not only possible to alter the catalytic properties of OpdA but it also demonstrated how remote "outer shell" amino acids may affect metal ion binding and thus enzyme stability [92,99]. Similarly, saturation mutagenesis at specific codons has been utilized to improve the catalytic efficiency of PTE toward poorly hydrolyzed P-S-bonds containing OPs such as Demeton-S, Malathion and VX [100]. Furthermore, a highly thermostable OPH has also been identified in the extremophile Deinococcus radiodurans, and which is stable at temperatures up to $70^{\circ} \mathrm{C}$ [101]. Site-directed- and random mutagenesis-based approaches were used to enhance the catalytic activity of this enzyme toward Ethyl and Methyl Paraoxon by 126- and 322-fold, respectively [101]. In view of the significant potential of OPHs in bioremediation the recent discovery of two "PTE-like" enzymes from Sphingomonas sp. strains TDK1 (i.e. Sm-PTE) and Sphingobium sp. strain TCM1 (i.e. Sb-PTE) is of interest [102]. These enzymes are particularly reactive toward a group of OP triesters that are frequently used as plasticizers, durable plastics, foams and flame retardants. These compounds, in contrast to OPs used as pesticides or nerve agents, do not have a labile ester bond and are not substrates for enzymes such as PTE or OpdA. Sb-PTE, however, is effective in hydrolyzing both inert and labile OPs, the latter albeit with an efficiency that is about two orders of magnitude smaller than that of PTE [103]. Nonetheless, using directed evolution approaches it may be possible to develop a stable enzymatic catalyst with a desired substrate preference. The structure of SbPTE is not yet known but there is no sequence homology to PTE or OpdA, and homology modeling suggested that its active site may contain a single divalent metal ion, thus resembling rather OPAAs such as PON1.

\section{Methyl parathion hydrolase (MPH)}

Methyl parathion (Fig. 1) is an OP pesticide extensively used in agriculture [104]. A genetic analysis of Plesiomonas sp. strain M6 and Pseudomonas sp. WBC-3 microbes that were found in methyl parathion-contaminated soil, has led to the discovery of an enzyme that effectively degrades this pesticide [105-107]. This enzyme was thus aptly named methyl parathion hydrolase (MPH). The enzyme from Plesiomonas sp. strain M6 (M6-MPH) and Pseudomonas sp. WBC-3 (WBC3-MPH) have identical protein and near-identical DNA sequences. Several MPH variants have since also been identified in other microorganisms, including Ochrobactum sp. and Burkholderia sp. [107-112]. MPH does not share any sequence similarity to OPHs such as PTE or OpdA.

The crystal structure of the homodimeric WBC3-MPH was solved to 2.4 Å resolution (Fig. 5) [113,114]. Similar to "Mazur type" OPAAs, PTE or OpdA the active site accommodates two metal ions, separated by $3.5 \AA$. However, while in OPAAs two bidentate carboxyl groups and in PTE/OpdA a bidentate, carboxylated lysine (all in $\mu-1,3$ coordination; Figs. 3 and 4) connect the two bound metal ions, in MPH an aspartate residue forms a $\mu-1,1$ link (Fig. 5). Insofar, the active site geometry of MPH is reminiscent of that of functionally unrelated dinuclear metallohydrolases such as purple acid phosphatases, Ser/Thr protein phosphatases or 5'-nucleotidases $[48,115,116]$. However, the highest degree of overall structural similarity is observed between MPH and another group of dinuclear metallohydrolases, the antibiotic-degrading metallo- $\beta$-lactamases (MBLs). Apart from the aspartate connecting the two metal ions all metal ion-binding residues in the active sites of MPH and MBLs are conserved $[113,114]$. MBLs generally require at least one $\mathrm{Zn}^{2+}$ ion for activity although the majority of these enzymes form dinuclear $\mathrm{Zn}^{2+}$ centers where the metal ion-bridging hydroxide acts as the initiator for the cleavage of the $\beta$-lactam bond [73,117]. MPH is also likely to contain dinuclear $\mathrm{Zn}^{2+}$ centers in its active site although in the crystal structure one of the $\mathrm{Zn}^{2+}$ ions was replaced by $\mathrm{Cd}^{2+}$,

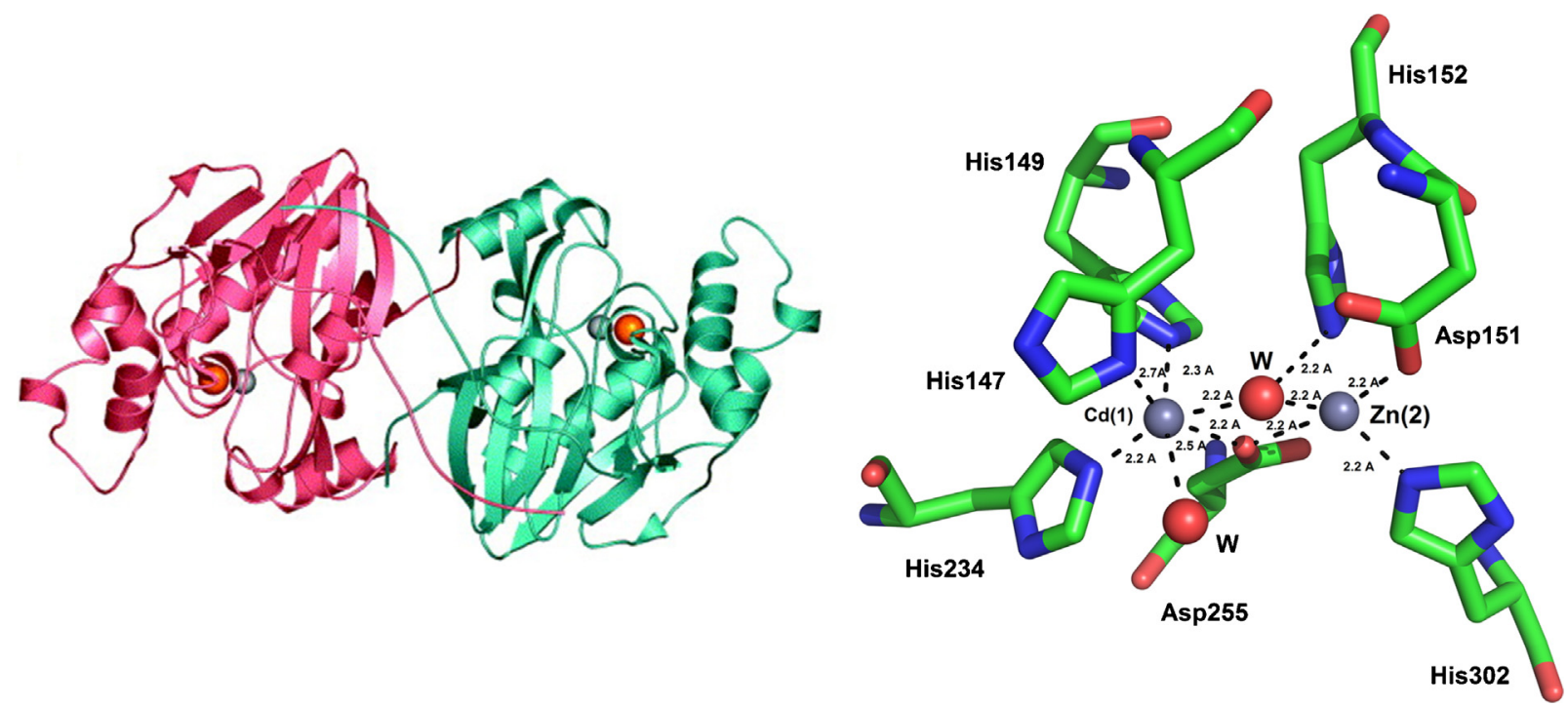

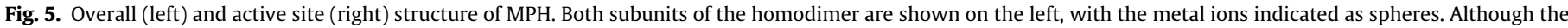

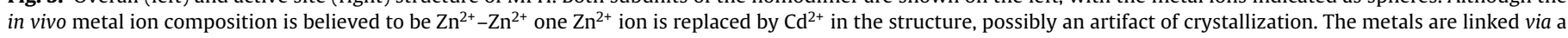
water bridge in addition to monodentate aspartate side chain. The figure was modified from [114]. 
present in the crystallization solution, and the relevant catalytic mechanism is proposed to be similar to that of PTE, OpdA or MBLs $[113,114]$. Furthermore, despite the lack of apparent sequence similarity between PTE/OpdA and MPH both groups of OPHs may have evolved from bacterial lactonase ancestor proteins, evidenced by the considerable lactonase activity measured for both PTE and the MPH-related MBLs MIM-1 and MIM-2 [118,119].

Importantly, since the MPH-fold appears to be capable of accommodating a diverse range of substrates ranging from OPs to $\beta$-lactams and lactones MPH may be a useful agent to be developed into a potent and versatile bioremediator. Toward this aim, site-directed and random mutagenesis, as well as a semi-rational approaches using computer-aided methods and site saturation mutagenesis have all been used to improve the thermal and acid stability of MPH from Ochrobactrum sp M231 [120-122]. Several groups have also been successful in increasing the activity of MPH toward less preferred substrates. Jeong and colleagues designed a high-throughput screening (HTS) system that utilizes a phenolicresponsive transcription activator for directed evolution of MPH and found a mutant with 100 -fold improvement in $k_{\text {cat }} / K_{\mathrm{m}}$ for the reaction using $p$-nitrophenyl diphenylphosphate as substrate [123]. Xie and co-workers subjected MPH from $P$. stutzeri strain ZK-5 to one round of error-prone PCR and found a mutant with a five-fold increase in $k_{\text {cat }}$ for the hydrolysis of Chlorpyrifos [124], while saturation mutagenesis and DNA shuffling experiments with WBC3-MPH demonstrated the plasticity of the active site of this enzyme since a modest number of mutations was required to finetune the substrate preference toward Ethyl Paraoxon [125].

Another $\mathrm{OPH}, \mathrm{OPHC}_{2}$, was isolated from P. pseudoalcaligenes [110]. This enzyme also belongs to the MBL superfamily and shares $\sim 45 \%$ sequence identity with MPH. Its structure was recently solved, revealing an overall fold and active site geometry virtually identical to that of WBC3-MPH (Fig. 5) [126,127]. However, while $\mathrm{OPHC}_{2}$ is catalytically less efficient than MPH it is more thermostable with a $T_{\mathrm{m}}$ of $97.8^{\circ} \mathrm{C}$, probably due to the presence of a disulfide bond that is absent in MPH. Thus, $\mathrm{OPHC}_{2}$ is an interesting candidate for future OP decontamination $[127,128]$.

\section{Glycerophosphodiesterase from Enterobacter aerogenes (GpdQ)}

GpdQ from E. aerogenes is one of the most promiscuous binuclear metallohydrolases, catalyzing the hydrolysis of all three classes of phosphate ester substrates, i.e. mono-, di- and triesters [129-132]. GpdQ has potential as an enzymatic bioremediator since it is active toward a range of organophosphate pesticides (triesters) and is capable of degrading EA2192, the highly toxic product of the hydrolysis of VX [133]. GpdQ is active over a very large $\mathrm{pH}$ range (from $\mathrm{pH} 3.0$ to 11 ) [130,131] and is also highly promiscuous with respect to metal ions that can be used to reconstitute catalytic activity $[130,131,134-137]$. While similar to PTE or OpdA it is unclear what the native metal ion composition of GpdQ may be, catalytic activity is highest for the dinuclear $\mathrm{Cd}^{2+}$ and $\mathrm{Mn}^{2+}$ derivatives, while activity can be reconstituted with the apoenzyme using a broad range of divalent transition metal ions [137]. In terms of sequence homology GpdQ is not related to any of the other known OP-degrading enzymes. Its closest relative is the diesterase Rv0805 from Mycobacterium tuberculosis, which hydrolyzes the diester bond in cyclic nucleotides and thus may play an essential role in cell signaling $[129,138]$.

Several crystal structures of GpdQ have been reported $[135,139,140]$, demonstrating an intricate homo-hexameric arrangements whereby six identical subunits form a trimer of dimers (Fig. 6). Each subunit contains an active site that can
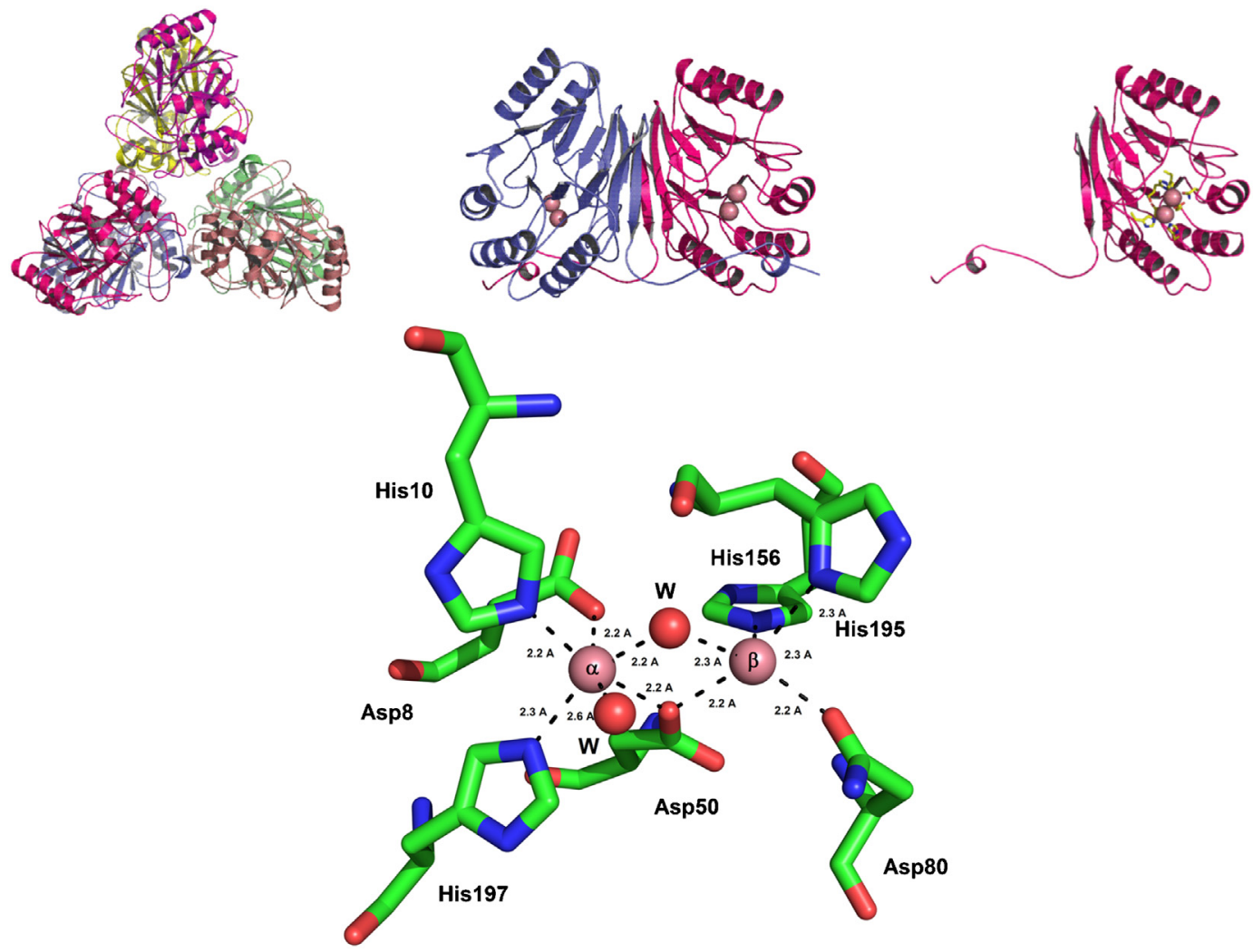

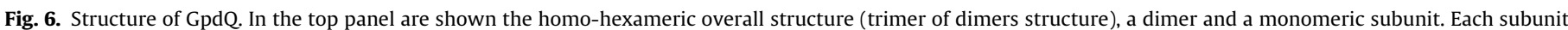

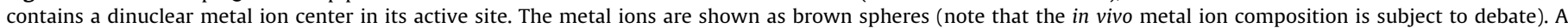

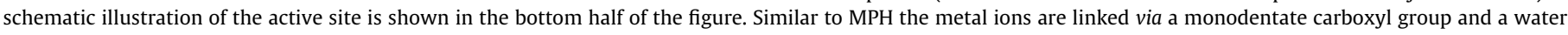
ligand. The figure was modified from [139]. 


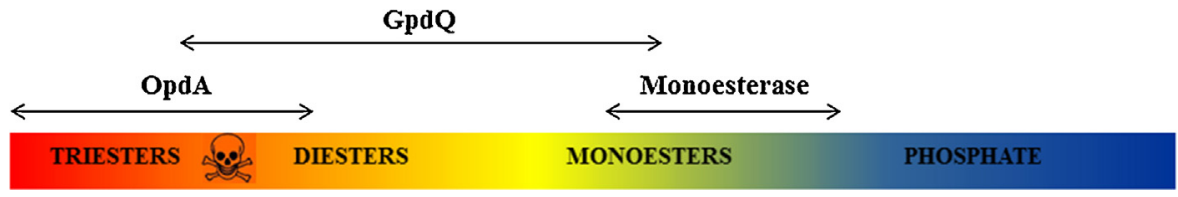

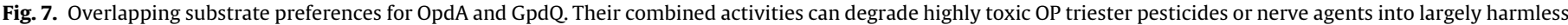
monoester products. These monoesters can easily be further metabolized into inorganic phosphate using a plethora of monoesterases.

accommodate two metal ions ( $\sim 3.5 \AA$ separation; Fig. 6). A series of spectroscopic and kinetic studies indicated that the dinuclear center is composed of a tightly bound, six-coordinate metal ion located in the $\alpha$ site and a more loosely bound, five-coordinate metal ion in the $\beta$ site $[130,131,139]$. Interestingly, despite having an identical coordination environment (with all seven metal ioncoordinating amino acids conserved) the diesterase Rv0805 binds both metal ions with high affinity, demonstrating the significance of outer sphere interactions in regulating the catalytically relevant metal ion center in these enzymes [138].

Indeed, GpdQ employs a regulatory mechanism to control its activity; in the resting state the enzyme is predominantly in an inactive mononuclear state (only one metal bound to the $\alpha$ site), but upon the addition of a substrate the enzyme is activated by the formation of a dinuclear metal center in the active site ("substrate-promoted" activation) $[130,139]$. The intricate regulatory mechanism employed by GpdQ complicates the enzyme's use for applications in bioremediation, for which a continuously active catalyst is of benefit. Mutations in the first and second coordination spheres were introduced to increase the affinity of the metal ion in the $\beta$ site in the absence of substrate molecules. In particular, mutations in the second coordination sphere (i.e. the replacement of His81, Ser127 and His217 by alanine) led to considerable improvements in metal ion binding affinities without affecting the catalytic performance of the enzyme [137,141]. Furthermore, directed evolution experiments have revealed that the catalytic efficiency (i.e. $\left.k_{\mathrm{cat}} / K_{\mathrm{m}}\right)$ toward model substrates such as bis(para-nitrophenol) phosphate can be improved over 500 -fold by the introduction of as few as three mutations, highlighting the strong potential of GpdQ in the development of a useful agent for bioremediation [142]

\section{Enzyme immobilization and biotechnological applications}

In general, enzymes may adopt a variety of roles in the environment, either as agents (in isolated, cell-bound or immobilized form) catalyzing the transformation and/or degradation of compounds polluting the environment, or as reliable and sensitive tools to detect and measure the amount and concentration of pollutants before, during and after the restoration process. There is a growing list of examples of enzymes employed (i) in biological remediation, (ii) in the transformation of pollutants to low-molecular weight additives, (iii) as biosensors used for monitoring levels of environmental pollution, and (iv) as bioindicators of water and soil quality [143]. Specifically, the previous sections highlighted the potential of a series of metal ion-dependent hydrolases in the detection and decontamination of various OP neurotoxins, including a range of pesticides and nerve agents (Fig. 1). A potentiometry-based biosensor for direct detection of OP nerve agents was developed by modifying a $\mathrm{pH}$ electrode with an immobilized layer of $E$. coli cells expressing PTE on their surface [144]. Since the PTE-catalyzed hydrolysis of OPs releases protons [89], the amount of hydrolyzed substrate can be easily measured. This biosensor can be stored longterm and is stable for multiple use [144]. PTE-based detection is fast and selective but not very sensitive. The detection sensitivity has been improved by using a carbon nanotube (CNT) as electrode material [145-149]. It has also been found that by using mesoporous carbon (MC) and carbon black (CB) along with PTE as an anodic layer, the sensitivity of the sensor for $p$-nitrophenol (PNP), a product of the PTE-catalyzed reaction, is greatly enhanced [150]. In comparison to the CNT-modified electrode the MC-CB modification results in an enhanced amperometric response because it promotes the electron transfer from the enzymatically generated phenolic compound (i.e. $p$-nitrophenol). Under optimal experimental conditions, the biosensor has a detection limit of $0.12 \mu \mathrm{M}(36 \mathrm{ppb})$ and a sensitivity of $198 \mathrm{nA} / \mu \mathrm{M}$ for paraoxon, which is suitable for biosensing applications [150]. An alternative biosensor includes the use of CdS quantum dots [151], where PTE and (CdSe)ZnS core-shell quantum dots (QDs) form a bioconjugate. Coupling of PTE to the (CdSe)ZnS core-shell QD was achieved through electrostatic interaction between the negatively charged QD surfaces and the positively charged protein side chain, and circular dichroism spectroscopy indicated that the activity of PTE was preserved. When applied to the monitoring of paraoxon levels the detection limit was determined to be about $10^{-8} \mathrm{M}$ [151].

Various current methods used for decontamination of OP compounds are environmentally challenging and include bleach treatment or ex situ incineration [152-157]. The successful incorporation of active PTE into aqueous fire-fighting foams was a breakthrough in the use of an enzymatic agent for surface decontamination; the method is reproducible, environmentally friendly and facilitates the decontamination of a larger area when compared to other methods [158]. Overlapping substrate preferences of several OP hydrolases may be exploited to degrade highly toxic OP triesters into less or non-toxic compounds. As illustrated in Fig. 7 OpdA and GpdQ are capable of converting toxic triesters into largely harmless monoesters; indeed an E. coli strain co-expressing both enzymes thrives in a medium where the OP paraoxon is the sole source for phosphorous [110]. GpdQ itself has low activity toward monoester substrates but there are numerous specialized monoesterases (e.g. purple acid phosphatases $[48,115,116]$ ) that can then convert the monoester substrates of the combined OpdA/GpdQ activity into inorganic phosphate. A current endeavor is thus to establish systems that employ both enzymes, preferably in an immobilized state to facilitate continuous use. Preliminary attempts to immobilize the OpdA-related enzyme OPH and GpdQ using mesoporous materials and magnetic nanoparticles, respectively, were encouraging since the process of immobilization led to increased stability and reactivity for both $[141,159,160]$.

Considering the great significance of enzyme immobilization for the effective application of these catalysts for applications such as environmental remediation and restoration it is informative to review some of the recent developments in this area. Nanostructures are attractive for enzymatic immobilization processes, since they possess ideal characteristics to optimize factors that determine the efficiency of the biocatalysts, including adaptable surface area, mass transfer resistance and effective enzyme loading. Enzyme supports include silica, chitosan, gold, diamond, metal ions and metal oxides, such as graphene and zirconium [161-171]. As mentioned in the previous paragraph advances have been made in immobilization processes that lead to improved enzyme stability, enhanced activity, but also the minimization of inhibition by 
reaction products and better selectivity toward desired substrates $[164,172]$. Another concrete example is the covalent attachment of cyclodextrin glycosyltransferase to magnetite (which was silanized with 3-aminopropyltrimethoxysilane and activated with glutaraldehyde), resulting in an adduct with increased thermal stability (i.e. the optimal temperature for activity was raised from $55^{\circ} \mathrm{C}$ to $70^{\circ} \mathrm{C}$ ) [168]. Other methods that may prove useful in developing a reusable devise for OP degradation include self-immobilization by the enzymes (e.g. cross-linked enzyme aggregates - CLEA), as well as encapsulation or entrapment using dendrispheres or PEI microspheres [169]. Enzyme immobilization on magnetic particles with functionalized surfaces has also recently been advanced to environmental applications, from enzymatic bioremediation to the synthesis of sustainable and clean energy through novel green processes [169]. The main advantages for using enzymes in such processes are their efficient catalytic properties, their biodegradability, as well as their high chemo-, regio and stereo-selectivity, resulting in low by-product formation. Furthermore, biomolecules linked to superparamagnetic nanoparticles can be selectively removed from complex reaction mixtures using an external magnetic field. For example, amino-functionalized superparamagnetic iron oxide nanoparticles (amino-SPION) were co-aggregated with penicillin $G$ acylase and then cross-linked, generating magnetic CLEAs (M-CLEAs) that were quickly and efficiently recovered from the reaction medium by applying an external magnetic field [166]. Another approach to exploit a magnetic field for separation was developed by adsorption of enzymes in superparamagnetic hierarchically ordered mesocellular mesoporous silica (M-HMMS) with subsequent enzyme crosslinking. Specifically, enzymes such as $\alpha-$ chymotrypsin or lipase were adsorbed into M-HMMS and treated with glutaraldehyde, which resulted in a crosslinked enzyme aggregate with sharply enhanced (i.e. >30-fold) activity when compared to the unlinked M-HMMS [173]. Also of interest is a method that facilitates a thermally-controlled switch for enzyme activity, an approach that is based on the site-directed conjugation of temperature-responsive polymers to a unique cysteine (Cys) residue positioned near the active site of the enzyme of interest. As an example, the reversible temperature-induced collapse of $N, N$ dimethylacrylamide (DMA)/ $N$-4-phenylazo-phenylacrylamide (AZAAm) copolymers (DMAAm) was used as a molecular switch to control the catalytic activity of endoglucanase [167]. Alternative approaches to enhance enzyme stability and activity for decontaminating OP neurotoxins are based on interactions between the hydrophobic polypropylene oxide (PPO) block of amphiphilic Pluronics and enzymes such as PTE. Although a detailed mechanism of how the PPO block may enhance the catalytic activity of OP-degrading enzymes has not yet been elucidated, it has been demonstrated that the aggregate has also increased resistance to inhibition by methanol, enhanced thermal stability, an extended shelf life, as well as an expanded substrate range [174]. Hydrogelforming PTE variants have also been generated by genetically fusing this enzyme to alpha-helical leucine zipper domains (H), unstructured soluble linker domains (S) and polyhistidine purification tags, resulting in the formation of hydrogels, which proved to be effective catalytic biomaterials [175]. Furthermore, in an attempt to improve long term stability and increase the half-life of such systems, PTE was immobilized on biocompatible gelatin pads [176]. In particular the use of glutaraldehyde spacers dramatically improves enzyme stability. These PTE-gelatin pads have proven effective to eliminate the OP-insecticide methyl parathion and the nerve agent sarin [176].

The development of a cell-based biosensor for OP detection (vide supra) demonstrates that whole cells of genetically engineered $E$. coli are an attractive alternative to using immobilized enzymes. An E. coli strain that displayed PTE on the cell surface has been used successfully (i) to detoxify contaminated wastewaters
[177] and (ii) for the biodetoxification of a widely used insecticide, coumaphos [178]. An E. coli strain that expressed a bacterial hemoglobin $(\mathrm{VHb})$ in addition to PTE is considerably more potent in degrading OPs such as paraoxon than the strain expressing PTE alone [176]. A genetically engineered $E$. coli strain expressing both a cellulose-binding domain (CBD) and PTE on its cell surface has been shown to promote the detoxification of OPs [110]. Subsequently, this $E$. coli strain was immobilized in a cellulose-coated hollow fiber bioreactor (HFB) and shown to be effective in the biodetoxification of a model OP pesticide, paraoxon [179]. It is envisioned that a combination of enzyme engineering (to improve their catalytic performance and structural stability) and immobilization, either using the enzymes alone or express them on the surface of carrier organisms such as E. coli may pave the way for very efficient and clean strategies to remove toxic compounds from environmentally challenged/polluted habitats.

Lastly, OP-degrading enzymes find increasing applications in medicine. OPs are estimated to cause the death of hundreds of thousands of people each year [1,24-27]. Human butyrylcholinesterase ( $\mathrm{hBChE}$ ) is a natural bioscavenger but the amount of native enzyme is insufficient to achieve reasonable protection. Of significance for medical applications is that intravenous pretreatment of patients with PTE prevents the inhibition of AChE activity after exposure to OPs and increases the recovery of this activity after poisoning [180]. PTE is thus a good candidate for use as catalytic bioscavenger for OP pesticides and nerve agents [181,182]. Recent trials with animals have shown that OpdA can also quickly clear most of the pesticides in the blood of poisoned rats [183]. Current limitations are the stability of the enzyme but attempts to overcome these limitations are currently being made using directed evolution methods. In addition, it could be shown that the covalent linking of enzymes such as PTE to polyethylene glycol (PEG) polymers increased the residence time of the foreign enzyme in the blood stream of guinea pigs and also reduced the production of anti-PTE antibodies [180]. Furthermore, it could also be demonstrated that the antidotal effects of OPAA from Alteromonas strain JD6.5 are significantly enhanced when the enzyme was encapsulated in liposomes [180]. Bioremediation by OP-degrading enzymes has the potential to become a major contributor to solving pesticide contaminations that lead to environmental pollution and human poisoning.

\section{Concluding remarks}

As the global population is rapidly increasing OP-based compounds are likely to remain an essential part for agriculture to meet the challenge of an ever growing demand for food. Consequently, the strain on the environment will also grow, making the development of efficient tools for bioremediation tools a high priority task. OP-degrading enzymes form the most promising avenue available for this endeavor. The challenge is to optimize such enzymes to withstand the pressures of the environment (i.e. temperature, $\mathrm{pH}$ ), and to be sufficiently versatile to operate on a range of commonly used OP compounds. Significant advances toward these aims have been made using various mutagenesisand evolution-type methods, but the process is ongoing. Similarly, optimal methods for the immobilization of these enzymes are still being investigated - the aim is to develop catalysts with desired catalytic properties that can be easily and continuously handled in an applied setting. In summary, this review highlighted the promise enzymes have in this area, and how they can be manipulated, but it also points out the current limitations in terms of their biotechnological applications. It is hoped that the motivated reader will draw inspiration and encouragement from this article to further develop these enzyme systems into versatile bioremedial agents. 


\section{Acknowledgements}

The authors thank the Australian Research Council (ARC DP150104358) for funding. GS and NM gratefully acknowledge receipt of an ARC Future Fellowship (FT120100694) and a Science Foundation Ireland - President of Ireland Young Researcher Award, respectively.

\section{References}

[1] W. Aktar, D. Sengupta, A. Chowdhury, Interdiscip. Toxicol. 2 (2009) 1.

[2] M.C.R. Alavanja, Rev. Environ. Health 24 (2009) 303.

[3] W.J. Zhang, F.B. Jiang, J.F. Ou, Proc. Int. Acad. Ecol. Environ. Sci. 1 (2011) 125.

[4] B.K. Singh, Nat. Rev. Microbiol. 7 (2009) 156

[5] V. Pitschmann, Toxins 6 (2014) 1761.

[6] M.B. Abou-Donia, Arch. Environ. Health 58 (2003) 484.

[7] K.V. Ragnarsdottir, J. Geol. Soc. 157 (2000) 859.

[8] B. Gonzalez-Alzaga, A.F. Hernandez, M. Rodriguez-Barranco, I. Gomez, C. Aguilar-Garduno, I. Lopez-Flores, T. Parron, M. Lacasana, Environ. Int. 85 (2015) 229.

[9] S. Norkaew, S. Lertmaharit, W. Wilaiwan, W. Siriwong, H.M. Perez, M.G. Robson, Rocz. Panstw. Zakl. Hig. 66 (2015) 21.

[10] K. Huen, A. Bradman, K. Harley, P. Yousefi, D. Boyd Barr, B. Eskenazi, N. Holland, Environ. Res. 117 (2012) 8.

[11] M. Fareed, C.N. Kesavachandran, M.K. Pathak, V. Bihari, M. Kuddus, A.K. Srivastava, Toxicol. Environ. Chem. 94 (2012) 1601

[12] W. Griffith, C.L. Curl, R.A. Fenske, C.A. Lu, E.M. Vigoren, E.M. Faustman, Environ. Res. 111 (2011) 751

[13] T. Nasrabadi, G.N. Bidhendi, A. Karbassi, P. Grathwohl, N. Mehrdadi, Environ. Earth Sci. 63 (2011) 873

[14] R. Mahajan, A. Blair, C.F. Lynch, P. Schroeder, J.A. Hoppin, D.P. Sandler, M.C.R. Alavanja, Environ. Health Perspect. 114 (2006) 1838.

[15] R. Mahajan, M.R. Bonner, J.A. Hoppin, M.C.R. Alavanja, Environ. Health Perspect. 114 (2006) 1205.

[16] C. Petchuay, P. Visuthismajarn, B. Vitayavirasak, P. Hore, M.G. Robson, Int. J. Occup. Environ. Health 12 (2006) 134.

[17] B.S. Anderson, B.M. Phillips, J.W. Hunt, K. Worcester, M. Adams, N. Kapellas, R.S. Tjeerdema, Environ. Toxicol. Chem. 25 (2006) 1160.

[18] M. Harnly, R. McLaughlin, A. Bradman, M. Anderson, R. Gunier, Environ. Health Perspect. 113 (2005) 1184.

[19] W.E. Lambert, M. Lasarev, J. Muniz, J. Scherer, J. Rothlein, J. Santana, L. McCauley, Environ. Health Perspect. 113 (2005) 504.

[20] B. Eskenazi, K. Harley, A. Bradman, E. Weltzien, N.P. Jewell, D.B. Barr, C.E. Furlong, N.T. Holland, Environ. Health Perspect. 112 (2004) 1116.

[21] G.D. Coronado, B. Thompson, L. Strong, W.C. Griffith, I. Islas, Environ. Health Perspect. 112 (2004) 142.

[22] S.E. Bellibas, I. Tuglular, Turk. J. Med. Sci. 20 (1994) 9

[23] C. Karr, J. Agromed. 17 (2012) 127.

[24] R. Ahmad, K. Ahad, R. Iqbal, A. Muhammad, Pak. J. Med. 18 (2002) 227.

[25] D. Gunnell, M. Eddleston, M.R. Phillips, F. Konradsen, BMC Public Health 7 (2007) 357.

[26] D. Payne-Sturges, J. Cohen, R. Castorina, D.A. Axelrad, T.J. Woodruff, Environ. Sci. Technol. 43 (2009) 7924.

[27] M. Eddleston, L. Karalliedde, N. Buckley, R. Fernando, G. Hutchinson, G. Isbister, F. Konradsen, D. Murray, J.C. Piola, N. Senanayake, R. Sheriff, S. Singh, S.B. Siwach, L. Smit, Lancet 360 (2002) 1163.

[28] X. Wang, Z. Li, H. Zhang, J. Xu, P. Qi, H. Xu, Q. Wang, X. Wang, Environ. Sci. Technol. 47 (2013) 9233.

[29] M.S. Hossain, M.A.Z. Chowdhury, M.K. Pramanik, M.A. Rahman, A.N.M. Fakhruddin, M.K. Alam, Appl. Water Sci. 5 (2015) 171.

[30] H.M. Balan, O.A. Kharchenko, N.N. Bubalo, Suchasni Probl. Toksikol., Kharchovoi Khim. Bezpeki (2013) 22.

[31] M. Fareed, M.K. Pathak, V. Bihari, R. Kamal, A.K. Srivastava, C.N. Kesavachandran, PLOS ONE 8 (2013) e69755.

[32] B. Kumar, R. Gaur, G. Goel, M. Mishra, S.K. Singh, D. Prakash, S. Kumar, C.S. Sharma, Electron. J. Environ., Agric. Food Chem. 11 (2012) 328.

[33] S. Jaipieam, P. Visuthismajarn, P. Sutheravut, W. Siriwong, S. Thoumsang, M. Borjan, M. Robson, Hum. Ecol. Risk Assess. 15 (2009) 1304.

[34] Y. Luo, M. Zhang, J. Environ. Qual. 38 (2009) 664

[35] L.L. Reys, Medico 1539 (1981) 417.

[36] J.E. Swift, Organophosphate Exposure from Agricultural Usage, Univ. California, 1976, pp. 264.

[37] J. Jindrichova, V. Ruekl, Prakt. Lek. 19 (1967) 449.

[38] S.K. Rastogi, S. Tripathi, D. Ravishanker, Indian J. Occup. Environ. Med. 14 (2010) 54.

[39] B.L. Waddell, S.H. Zahm, D. Baris, D.D. Weisenburger, F. Holmes, L.F. Burmeister, K.P. Cantor, A. Blair, Cancer Causes Control 12 (2001) 509.

[40] R.D. Richins, I. Kaneva, A. Muchandani, W. Chen, Nat. Biotechnol. 15 (1997) 984.

[41] C.M. Theriot, A.M. Grunden, Appl. Microbiol. Biotechnol. 89 (2011) 35.

[42] T. Khumsaeng, T.K.O. Nguyen, K.H. Kare, C. Polprasert, Waste Manage. 33 (2013) 833.
[43] A. Ratna Kumari, K. Sobha, K. Mounika, G.J. Nageswara Rao, M. Ashok, Int. J. Life Sci. Biotechnol. Pharma Res. 1 (2012) 64.

[44] A. Mazur, J. Biol. Chem. 164 (1946) 271.

[45] N. Sethunathan, T. Yoshida, Can. J. Microbiol. 19 (1973) 873.

[46] E. Ghanem, F.M. Raushel, Toxicol. Appl. Pharmacol. 207 (2005) S459.

[47] F. Ely, J.-L. Foo, C.J. Jackson, L.R. Gahan, D. Ollis, G. Schenk, Curr. Top. Biochem. Res. 9 (2007) 63.

[48] G. Schenk, N. Mitic, L.R. Gahan, D.L. Ollis, R.P. McGeary, L.W. Guddat, Acc Chem. Res. 45 (2012) 1593.

[49] R.D. Newcomb, P.M. Campbell, D.L. Ollis, E. Cheah, R.J. Russell, J.G. Oakeshott, Proc. Natl. Acad. Sci. U. S. A. 94 (1997) 7464.

[50] W.N. Aldridge, Biochem. J. 53 (1953) 110.

[51] W.N. Aldridge, Biochem. J. 53 (1953) 117.

[52] D.I. Draganov, B.N. La Du, Naunyn Schmiedebergs Arch. Pharmacol. 369 (2004) 78.

[53] D.I. Draganov, J.F. Teiber, A. Speelman, Y. Osawa, R. Sunahara, B.N. La Du, J Lipid Res. 46 (2005) 1239.

[54] O. Khersonsky, D.S. Tawfik, Biochemistry 44 (2005) 6371.

[55] B. Fuhrman, N. Volkova, M. Aviram, Atherosclerosis 161 (2002) 307.

[56] D. Litvinov, H. Mahini, M. Garelnabi, N. Am. J. Med. Sci. 4 (2012) 523

[57] O. Rozenberg, D.M. Shih, M. Aviram, Arterioscler. Thromb. Vasc. Biol. 23 (2003) 461.

[58] C.-L. Kuo, B.N. La Du, Drug Metab. Dispos. 26 (1998) 653.

[59] J.J. Ceron, F. Tecles, A. Tvarijonaviciute, BMC Vet. Res. 10 (1) (2014) 74

[60] M. Harel, A. Aharoni, L. Gaidukov, B. Brumshtein, O. Khersonsky, R. Meged, H. Dvir, R.B.G. Ravelli, A. McCarthy, L. Toker, I. Silman, J.L. Sussman, D.S. Tawfik, Nat. Struct. Mol. Biol. 11 (2004) 412.

[61] F.C.G. Hoskin, J.E. Walker, C.M. Mello, Chem. Biol. Interact. 119-120 (1999) 399.

[62] F.C.G. Hoskin, D.M. Steeves, J.E. Walker, C.T. Woodbury, Biochem. Pharmacol 46 (1993) 1223.

[63] J.J. DeFrank, T.C. Cheng J. Bacteriol. 173 (1991) 1938.

[64] F.C.G. Hoskin, A.H. Roush, Science 215 (1982) 1255

[65] T.C. Cheng, S.P. Harvey, A.N. Stroup, Appl. Environ. Microbiol. 59 (1993) 3138

[66] T.C. Cheng, L. Liu, B. Wang, J. Wu, J.J. DeFrank, D.M. Anderson, V.K. Rastogi, A.B. Hamilton, J. Ind. Microbiol. Biotechnol. 18 (1997) 49.

[67] T.-C. Cheng, J.J. DeFrank, V.K. Rastogi, Chem. Biol. Interact. 119-120 (1999) 455.

[68] A. Stepankova, J. Duskova, T. Skalova, J. Hasek, T. Koval, L.H. Ostergaard, J. Dohnalek, Acta Crystallogr. 69 (2013) 346.

[69] N.K. Vyas, A. Nickitenko, V.K. Rastogi, S.S. Shah, F.A. Quiocho, Biochemistry 49 (2010) 547.

[70] S.C. Graham, J.M. Guss, Arch. Biochem. Biophys. 469 (2008) 200.

[71] M.C.J. Wilce, C.S. Bond, N.E. Dixon, H.C. Freeman, J.M. Guss, P.E. Lilley, J.A Wilce, Proc. Natl. Acad. Sci. U. S. A. 95 (1998) 3472.

[72] W.T. Lowther, Y. Zhang, P.B. Sampson, J.F. Honek, B.W. Matthews, Biochemistry 38 (1999) 14810.

[73] N. Mitic, M. Miraula, C. Selleck, K.S. Hadler, M.M. Pedroso, E. Uribe, G. Schenk in: C.Z. Christov (Ed.), Adv. Protein Chem. Struct. Biol., Elsevier, Oxford, 2014, p. 49.

[74] A.J. Copik, B.P. Nocek, S.I. Swierczek, S. Ruebush, S.B. Jang, M. Lu, V.M. D’Souza, J.W. Peters, B. Bennett, R.C. Holz, Biochemistry 44 (2005) 121.

[75] M.J. Maher, M. Ghosh, A.M. Grunden, A.L. Menon, M.W.W. Adams, H.C. Freeman, J.M. Guss, Biochemistry 43 (2004) 2771.

[76] T.-C. Cheng, S.P. Harvey, G.L. Chen, Appl. Environ. Microbiol. 62 (1996) 1636

[77] C.M. Theriot, X.-L. Du, S.R. Tove, A.M. Grunden, Appl. Microbiol. Biotechnol. 87 (2010) 1715.

[78] C.M. Theriot, R.L. Semcer, S.S. Shah, A.M. Grunden, Archaea (2011) 565127.

[79] J.K. Grimsley, J.M. Scholtz, C.N. Pace, J.R. Wild, Biochemistry 36 (1997) 14366

[80] F.M. Raushel, Curr. Opin. Microbiol. 5 (2002) 288.

[81] D.M. Munnecke, Appl. Environ. Microbiol. 32 (1976) 7

[82] C.M. Hill, W.-S. Li, T.-C. Cheng, J.J. DeFrank, F.M. Raushel, Bioorg. Chem. 29 (2001) 27

[83] C.M. Hill, F. Wu, T.-C. Cheng, J.J. DeFrank, F.M. Raushel, Bioorg. Med. Chem. Lett. 10 (2000) 1285.

[84] J.K. Grimsley, B. Calamini, J.R. Wild, A.D. Mesecar, Arch. Biochem. Biophys. 442 (2005) 169.

[85] C.M.-H. Cho, A. Mulchandani, W. Chen, Appl. Environ. Microbiol. 70 (2004) 4681.

[86] M.M. Benning, H. Shim, F.M. Raushel, H.M. Holden, Biochemistry 40 (2001) 2712.

[87] J. Kim, P.-C. Tsai, S.-L. Chen, F. Himo, S.C. Almo, F.M. Raushel, Biochemistry 47 (2008) 9497.

[88] M. Chen-Goodspeed, M.A. Sogorb, F. Wu, S.-B. Hong, F.M. Raushel, Biochemistry 40 (2001) 1325.

[89] S.D. Aubert, Y. Li, F.M. Raushel, Biochemistry 43 (2004) 5707.

[90] M.M. Pedroso, F. Ely, N. Mitic, M.C. Carpenter, L.R. Gahan, D.E. Wilcox, J.L. Larrabee, D.L. Ollis, G. Schenk, J. Biol. Inorg. Chem. 19 (2014) 1263.

[91] H. Yang, P.D. Carr, S.Y. McLoughlin, J.W. Liu, I. Horne, X. Qiu, C.M.J. Jeffries, R.J Russell, J.G. Oakeshott, D.L. Ollis, Protein Eng. 16 (2003) 135

[92] J.-L. Foo, C.J. Jackson, P.D. Carr, H.-K. Kim, G. Schenk, L.R. Gahan, D.L. Ollis, Biochem. J. 429 (2010) 313.

[93] F. Ely, K.S. Hadler, L.R. Gahan, L.W. Guddat, D.L. Ollis, G. Schenk, Biochem. J 432 (2010) 565.

[94] F. Ely, M.M. Pedroso, L.R. Gahan, D.L. Ollis, L.W. Guddat, G. Schenk, J. Inorg. Biochem. 106 (2012) 19. 
[95] C.J. Jackson, P.D. Carr, H.-K. Kim, J.-W. Liu, P. Herrald, N. Mitic, G. Schenk, C.A. Smith, D.L. Ollis, Biochem. J. 397 (2006) 501.

[96] F. Ely, K.S. Hadler, N. Mitic, L.R. Gahan, D.L. Ollis, N.M. Plugis, M.T. Russo, J.A. Larrabee, G. Schenk, J. Biol. Inorg. Chem. 16 (2011) 777

[97] S.Y. McLoughlin, C. Jackson, J.-W. Liu, D. Ollis, Protein Expression Purif. 41 (2005) 433.

[98] S.Y. McLoughlin, C. Jackson, J.-W. Liu, D.L. Ollis, Appl. Environ. Microbiol. 70 (2004) 404

[99] C.J. Jackson, J.L. Foo, N. Tokuriki, L. Afriat, P.D. Carr, H.K. Kim, G. Schenk, D.S. Tawfik, D.L. Ollis, Proc. Natl. Acad. Sci. U. S. A. 106 (2009) 21631

[100] D.A. Schofield, A.A. Dinovo, J. Appl. Microbiol. 109 (2010) 548

[101] R. Hawwa, S.D. Larsen, K. Ratia, A.D. Mesecar, J. Mol. Biol. 393 (2009) 36

[102] K. Abe, S. Yoshida, Y. Suzuki, J. Mori, Y. Doi, S. Takahashi, Y. Kera, Appl. Environ. Microbiol. 80 (2014) 5866.

[103] D.F. Xiang, A.N. Bigley, Z. Ren, H. Xue, K.G. Hull, D. Romo, F.M. Raushel, Biochemistry 54 (2015) 7595.

[104] R.S. Verma, A. Mehta, N. Srivastava, Pestic. Biochem. Physiol. 95 (2009) 152.

[105] Y. Chen, X. Zhang, H. Liu, Y. Wang, X. Xia, Wei Sheng Wu Xue Bao 42 (2002) 490.

[106] Z. Cui, S. Li, G. Fu, Appl. Environ. Microbiol. 67 (2001) 4922.

[107] H. Liu, J.-J. Zhang, S.-J. Wang, X.-E. Zhang, N.-Y. Zhou, Biochem. Biophys. Res. Commun. 334 (2005) 1107.

[108] A. Ekkhunnatham, B. Jongsareejit, W. Yamkunthong, J. Wichitwechkarn, World J. Microbiol. Biotechnol. 28 (2012) 1739.

[109] X. Li, J. Jiang, L. Gu, S.W. Ali, J. He, S. Li, Int. Biodeterior. Biodegrad. 62 (2008) 331.

[110] N. Wu, M. Deng, X. Shi, G. Liang, B. Yao, Y. Fan, Chin. Sci. Bull. 49 (2004) 268.

[111] C. Yang, N. Liu, X. Guo, C. Qiao, FEMS Microbiol. Lett. 265 (2006) 118.

[112] Z. Zhang, Q. Hong, J. Xu, X. Zhang, S. Li, Biodegradation 17 (2006) 275

[113] C. Bebrone, Biochem. Pharmacol. 74 (2007) 1686.

[114] Y.-J. Dong, M. Bartlam, L. Sun, Y.-F. Zhou, Z.-P. Zhang, C.-G. Zhang, Z. Rao, X.-E. Zhang, J. Mol. Biol. 353 (2005) 655.

[115] N. Mitic, S.J. Smith, A. Neves, L.W. Guddat, L.R. Gahan, G. Schenk, Chem. Rev. 106 (2006) 3338.

[116] G. Schenk, N. Mitic, G.R. Hanson, P. Comba, Coord. Chem. Rev. 257 (2013) 473.

[117] M.W. Crowder, J. Spencer, A.J. Vila, Acc. Chem. Res. 39 (2006) 721.

[118] M. Sirotkina, E.N. Efremenko, Appl. Microbiol. Biotechnol. 98 (2014) 2647

[119] M. Miraula, G. Schenk, N. Mitic, J. Inorg. Biochem. (2016), http://dx.doi.org/ 10.1016/j.jinorgbio.2015.12.014.

[120] L. Huang, P. Wang, J. Tian, H. Jiang, N. Wu, P. Yang, B. Yao, Y. Fan, Biotechnol. Lett. 34 (2012) 1115

[121] Y. Su, J. Tian, P. Wang, X. Chu, G. Liu, N. Wu, Y. Fan, Appl. Biochem. Biotechnol. 165 (2011) 989

[122] J. Tian, P. Wang, S. Gao, X. Chu, N. Wu, Y. Fan, FEBS J. 277 (2010) 4901.

[123] Y.-S. Jeong, S.-L. Choi, H.-H. Kyeong, J.-H. Kim, E.-J. Kim, J.-G. Pan, E. Rha, J.J. Song, S.-G. Lee, H.-S. Kim, Protein Eng., Des. Sel. 25 (2012) 725.

[124] J. Xie, Y. Zhao, H. Zhang, Z. Liu, Z. Lu, Lett. Appl. Microbiol. 58 (2014) 53.

[125] T.-K. Ng, L.R. Gahan, G. Schenk, D.L. Ollis, Arch. Biochem. Biophys. 573 (2015) 59.

[126] G. Gotthard, J. Hiblot, D. Gonzalez, E. Chabriere, M. Elias, Acta Crystallogr. 69 (2013) 73

[127] G. Gotthard, J. Hiblot, D. Gonzalez, M. Elias, E. Chabriere, PLOS ONE 8 (2013) e77995.

[128] X.-Y. Chu, J. Tian, N.-F. Wu, Y.-L. Fan, Appl. Microbiol. Biotechnol. 88 (2010) 125.

[129] K.S. Hadler, T. Huber, A.I. Cassady, J. Weber, J. Robinson, A. Burrows, G. Kelly, L.W. Guddat, D.A. Hume, G. Schenk, J.U. Flanagan, BMC Res. Notes 1 (2008) 78.

[130] K.S. Hadler, N. Mitic, F. Ely, G.R. Hanson, L.R. Gahan, J.A. Larrabee, D.L. Ollis, G. Schenk, J. Am. Chem. Soc. 131 (2009) 11900.

[131] K.S. Hadler, N. Mitic, S.H.-C. Yip, L.R. Gahan, D.L. Ollis, G. Schenk, J.A. Larrabee, Inorg. Chem. 49 (2010) 2727.

[132] T.J. Larson, M. Ehrmann, W. Boos, J. Biol. Chem. 258 (1983) 5428.

[133] E. Ghanem, Y. Li, C. Xu, F.M. Raushel, Biochemistry 46 (2007) 9032.

[134] K.S. Hadler, L.R. Gahan, D.L. Ollis, G. Schenk, J. Inorg. Biochem. 104 (2010) 211

[135] C.J. Jackson, K.S. Hadler, P.D. Carr, A.J. Oakley, S. Yip, G. Schenk, D.L. Ollis, Acta Crystallogr. 64 (2008) 681.

[136] R.E. Mirams, S.J. Smith, K.S. Hadler, D.L. Ollis, G. Schenk, L.R. Gahan, J. Biol. Inorg. Chem. 13 (2008) 1065.

[137] L.J. Daumann, B.Y. McCarthy, K.S. Hadler, T.P. Murray, L.R. Gahan, J.A. Larrabee, D.L. Ollis, G. Schenk, Biochim. Biophys. Acta 1834 (2013) 425.

[138] M.M. Pedroso, J.A. Larrabee, F. Ely, S.E. Gwee, N. Mitic, D.L. Ollis, L.R. Gahan, G. Schenk, Chem. Eur. J. 22 (2016) 999.

[139] K.S. Hadler, E.A. Tanifum, S.H.-C. Yip, N. Mitic, L.W. Guddat, C.J. Jackson, L.R. Gahan, K. Nguyen, P.D. Carr, D.L. Ollis, A.C. Hengge, J.A. Larrabee, G. Schenk, J. Am. Chem. Soc. 130 (2008) 14129.

[140] C.J. Jackson, P.D. Carr, J.-W. Liu, S.J. Watt, J.L. Beck, D.L. Ollis, J. Mol. Biol. 367 (2007) 1047.
[141] L.J. Daumann, J.A. Larrabee, D. Ollis, G. Schenk, L.R. Gahan, J. Inorg. Biochem. 131 (2014) 1.

[142] S.H.C. Yip, J.-L. Foo, G. Schenk, L.R. Gahan, P.D. Carr, D.L. Ollis, Protein Eng., Des. Sel. 24 (2011) 861.

[143] M.A. Rao, R. Scelza, F. Acevedo, M.C. Diez, L. Gianfreda, Chemosphere 107 (2014) 145.

[144] A. Mulchandani, P. Mulchandani, I. Kaneva, W. Chen, Anal. Chem. 70 (1998) 4140.

[145] P. Ramnani, N.M. Saucedo, A. Mulchandani, Chemosphere 143 (2016) 85

[146] N. Liu, X. Cai, Y. Lei, Q. Zhang, M.B. Chan-Park, C. Li, W. Chen, A. Mulchandani, Electroanalysis 19 (2007) 616

[147] K.A. Joshi, M. Prouza, M. Kum, J. Wang, J. Tang, R. Haddon, W. Chen, A. Mulchandani, Anal. Chem. 78 (2006) 331.

[148] R.P. Deo, J. Wang, I. Block, A. Mulchandani, K.A. Joshi, M. Trojanowicz, F. Scholz, W. Chen, Y. Lin, Anal. Chim. Acta 530 (2005) 185.

[149] K.A. Joshi, J. Tang, R. Haddon, J. Wang, W. Chen, A. Mulchandani, Electroanalysis 17 (2005) 54

[150] J.H. Lee, J.Y. Park, K. Min, H.J. Cha, S.S. Choi, Y.J. Yoo, Biosens. Bioelectron. 25 (2010) 1566.

[151] X. Ji, J. Zheng, J. Xu, V.K. Rastogi, T.-C. Cheng, J.J. DeFrank, R.M. Leblanc, J. Phys. Chem. B 109 (2005) 3793.

[152] Y.J. Jang, K. Kim, O.G. Tsay, D.G. Churchill, D.A. Atwood, D.G. Churchill, Chem Rev 115 (2015) PR1.

[153] T. Castelo-Grande, P.A. Augusto, P. Monteiro, A.M. Estevez, D. Barbosa, Int. J. Environ. Anal. Chem. 90 (2010) 438

[154] Z. Amirova, E. Kruglov, V. Maystrenko, F. Khizbullin, Organohalogen Compd. 68 (2006) 2318.

[155] R.C. Putnam, F. Ellison, R. Protzmann, J. Hilovsky, Organic Pesticides and Pesticide Containers. Decontamination and combustion, Foster D. Snell, Inc., 1971, pp. 182.

[156] M.V. Kennedy, B.J. Stojanovic, F.L. Shuman Jr., Residue Rev. 29 (1969) 89.

[157] K. Kim, O.G. Tsay, D.A. Atwood, D.G. Churchill, Chem. Rev. 111 (2011) 5345

[158] K.E. LeJeune, J.R. Wild, A.J. Russell, Nature 395 (1998) 27.

[159] K. El-Boubbou, D.A. Schofield, C.C. Landry, J. Phys. Chem. C 116 (2012) 17501

[160] K. El-Boubbou, D.A. Schofield, C.C. Landry, Adv. Healthcare Mater. 1 (2012) 183.

[161] K.C. de Souza, N.D.S. Mohallem, E.M. Barros de Sousa, Quim. Nova 34 (2011) 1692.

[162] U.T. Bornscheuer, Angew. Chem., Int. Ed. 42 (2003) 3336

[163] E.P. Cipolatti, M.J.A. Silva, M. Klein, V. Feddern, M.M.C. Feltes, J.V. Oliveira, J.L. Ninow, D. de Oliveira, J. Mol. Catal. B: Enzym. 99 (2014) 56.

[164] C. Mateo, J.M. Palomo, G. Fernandez-Lorente, J.M. Guisan, R. FernandezLafuente, Enzyme Microb. Technol. 40 (2007) 1451.

[165] R.-S. Juang, F.-C. Wu, R.-L. Tseng, Adv. Environ. Res. 6 (2002) 171

[166] W. Kopp, T.P. da Costa, S.C. Pereira, M. Jafelicci Jr., R.C. Giordano, R.F.C. Marques, F.M. Araujo-Moreira, R.L.C. Giordano, Process Biochem. 49 (2014) 38.

[167] T. Shimoboji, E. Larenas, T. Fowler, A.S. Hoffman, P.S. Stayton, Bioconjugate Chem. 14 (2003) 517.

[168] K.C. Blanco, F.J. dos Santos, N.S. Bernardi, M. Jafelicci Jr., R. Monti, J. Contiero, Enzyme Eng. 2 (2013) 1000111.

[169] D. Brady, J. Jordaan, Biotechnol. Lett. 31 (2009) 1639

[170] M.M. Milani, A.S. Lotfi, A. Mohsenifar, P. Mikaili, N. Kamelipour, J. Dehghan, Res. J. Environ. Toxicol. 9 (2015) 34

[171] A.A. Wang, W. Chen, A. Mulchandani, Biotechnol. Bioeng. 91 (2005) 379.

[172] T. Montes, V. Grazu, F. Lopez-Gallego, J.A. Hermoso, J.L. Garcia, I. Manso, B. Galan, R. Gonzalez, R. Fernandez-Lafuente, J.M. Guisan, Appl. Environ. Microbiol. 73 (2007) 312 .

[173] J. Lee, H.B. Na, B.C. Kim, J.H. Lee, B. Lee, J.H. Kwak, Y. Hwang, J.-G. Park, M.B. Gu, J. Kim, J. Joo, C.-H. Shin, J.W. Grate, T. Hyeon, J. Kim, J. Mater. Chem. 19 (2009) 7864.

[174] M. Kim, M. Gkikas, A. Huang, J.W. Kang, N. Suthiwangcharoen, R. Nagarajan, B.D. Olsen, Chem. Commun. 50 (2014) 5345.

[175] H.D. Lu, I.R. Wheeldon, S. Banta, Protein Eng., Des. Sel. 23 (2010) 559.

[176] A.K. Kanugula, E.R. Repalle, J.P. Pandey, G. Sripad, C.K. Mitra, D.K. Dubey, D. Siddavattam, Indian J. Biochem. Biophys. 48 (2011) 29.

[177] A. Mulchandani, I. Kaneva, W. Chen, Biotechnol. Bioeng. 63 (1999) 216.

[178] A.H. Mansee, W. Chen, A. Mulchandani, Biotechnol. Bioprocess Eng. 5 (2000) 436.

[179] A.H. Mansee, W. Chen, A. Mulchandani, J. Ind. Microbiol. Biotechnol. 32 (2005) 554.

[180] K. Tuovinen, E. Kaliste-Korhonen, F.M. Raushel, O. Hanninen, Fundam. Appl. Toxicol. 23 (1994) 578.

[181] M. Balali-Mood, H. Saber, Iran J. Med. Sci. 37 (2012) 74.

[182] M. Trovaslet-Leroy, L. Musilova, F. Renault, X. Brazzolotto, J. Misik, L. Novotny, M.-T. Froment, E. Gillon, M. Loiodice, L. Verdier, P. Masson, D. Rochu, D. Jun, F. Nachon, Toxicol. Lett. 206 (2011) 14.

[183] S.B. Bird, T.D. Sutherland, C. Gresham, J. Oakeshott, C. Scott, M. Eddleston, Toxicology 247 (2008) 88. 